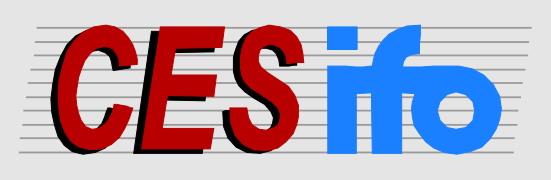

\title{
Working
}

Papers

www.cesifo.org/wp

\section{Austerity, Growth and Inflation. Remarks on the Eurozone's Unresolved Competitiveness Problem}

\author{
Hans-Werner Sinn \\ CESIFO WORKING PAPER NO. 4086 \\ CATEgory 6: Fiscal Policy, Macroeconomics and Growth \\ JANUARY 2013 \\ An electronic version of the paper may be downloaded \\ - from the SSRN website: Www.SSRN.com \\ - from the RePEc website: $\quad$ www.RePEc.org \\ - from the CESifo website: www.CESifo-group.org/wp
}

\section{CESifo}




\title{
Austerity, Growth and Inflation. Remarks on the Eurozone’s Unresolved Competitiveness Problem
}

\begin{abstract}
While the financial protection measures enacted by the ECB and the community of Eurozone members have calmed financial markets, they have left the competitiveness problem of the Eurozone's southern countries and France unresolved. The paper compares price inflation before the crisis with the necessary and actual price cuts that have taken place since the outbreak of the crisis, predicting a decade of stagnation for the south and inflation for the north. Keynesian demand policy is counterproductive in the south and unnecessary in the north. The necessary realignment of relative goods prices and current account imbalances can be achieved if market forces are allowed to redirect capital flows to the north instead of being artificially steered to uses they are keen to avoid.
\end{abstract}

JEL-Code: E310, E610, E620, F310, F320, F340, H620, H630.

Keywords: competitiveness, inflation, realignment, Keynesian policy.

\author{
Hans-Werner Sinn \\ Ifo Institute - Leibniz-Institute for \\ Economic Research at the University of Munich \\ Poschingerstraße 5 \\ 81679 Munich \\ Germany \\ sinn@ifo.de
}

This text is an extension of Sinn (2012), Chapters 1, 3 and 4. It was prepared for the Interparliamentary Committee Meeting at the European Parliament, DG Internal Policies of the Union Policy, Department A - ECON, and presented on 29 January 2013 in Brussels. 
Many European leaders have advocated growth programs for Europe's crisis stricken countries, meaning in fact debt-financed expenditure programs. In this note I will argue that such programs are not the right medicine, since the Eurozone suffers from an internal competitiveness problem rather than a temporary lack of demand. They would provide temporary stimulus and relief, but at the expense of postponing the long-term adjustments that are needed to improve the competitiveness of the crisis-stricken countries. They are a painkiller that dampens the symptoms but does nothing to cure the underlying illness. What Europe needs is austerity in the south and inflationary growth in the north to improve the competitiveness of the south and to structurally improve the current account imbalances. However, instead of taking hectic policy actions, what this requires is simply more tolerance towards market forces that are already working in this direction.

The financial crisis has calmed down somewhat, thanks to the fact that the ESM and the ECB stand ready to buy any troubled country's government bonds if bankruptcy looms, hence shifting the burden of write-off losses, or of transfers aimed at preventing such losses, to the taxpayers of the Eurozone's still-solid economies. This has provided a respite, but it is not a contribution to a real solution of the Eurozone's problems.

\section{The competitiveness problem}

The unresolved problem underlying the financial crisis is the lack of competitiveness of the southern European countries and France. If anything, placating investors with taxpayer guarantees postpones the necessary painful adjustments through which competitiveness could be restored.

The lack of competitiveness was brought about by the euro itself. The announcement of irrevocable commitment to it at the Madrid Summit of December 1995, three years before its actual introduction in 1999, caused interest rates to converge, making cheap credit available to southern Europe and Ireland. The exchange rate risk that had hitherto caused huge interest spreads disappeared and the risk of state bankruptcy, which recently again caused huge interest spreads, was not yet on the radar. Both the political protection implicit in the Eurosystem, and the EU's interpretation of the Basel Accords that encouraged banks and insurance companies to gobble up southern European government bonds because no equity had to be held against such bonds, led to the risk of state bankruptcy being neglected. The upshot was an overabundance of cheap credit for southern Europe and Ireland, which fuelled an inflationary boom that initially helped the periphery to converge, but gained too much 
momentum and finally turned into a bubble that burst in 2007, when the American financial crisis swept over to Europe. ${ }^{1}$

In Greece and Portugal the government sectors used the credit to raise public-sector wages and hire more public employees, while in Spain and Ireland investors borrowed to buy real estate and build houses. In the end it made no difference how the credit entered the economy. In Greece government employees built homes with their credit-financed income and in Spain the construction workers paid taxes out of their credit financed wages to the state. In addition, the Spanish state collected a property tax, whose revenue increased enormously during the real estate bubble. The other sectors benefited as well in both cases.

As is shown in Figure 1, during the bubble, from the year of the Madrid Summit (1995) to the year of the Lehman crisis (2008), the Greek price level (GDP deflator) increased by $67 \%$, the Spanish one by $56 \%$, the Irish one by $53 \%$, and the Portuguese one by $47 \%$. By comparison, the average price increase of the countries now in the Eurozone was 26\%, while Germany's price level increased only by $9 \%$.

However, some currencies openly depreciated and others openly appreciated before the exchange rates were irrevocably fixed. Taking both the exchange rate adjustments and the price changes into account, it turns out that Greece appreciated by $18 \%$ relative to the rest of the Eurozone, Spain by 22\%, Ireland by $30 \%$, and Portugal by $14 \%$. These numbers look relatively more moderate, since the respective rest of the Eurozone they relate to includes many other countries that also appreciated. If the GIPSIC countries are taken together, and if both price changes and exchange rate adjustments since 1995 are considered, the total rate of appreciation relative to the rest of the Eurozone from 1995 to 2008 was 30\%. The countries in the southern and western periphery lost their competitiveness simply by becoming too expensive.

\footnotetext{
${ }^{1}$ See Sinn and Koll (2000) and Sinn (2010).
} 
Figure 1: Development of the GDP deflator from 1995 to 2008

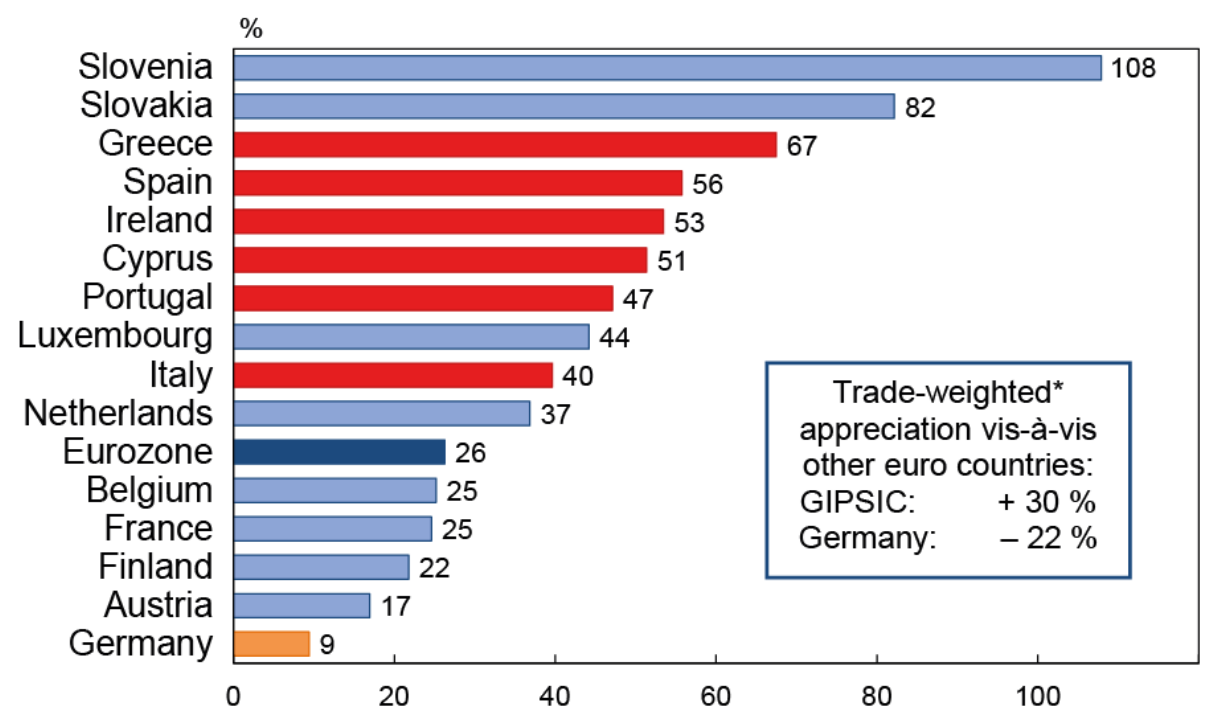

* Including exchange rate adjustments before the introduction of the euro.

Source: Eurostat, Database, Economy and Finance, National accounts, GDP and main components - Price indices; Ifo Institute calculations.

The Balassa-Samuelson effect, which is sometimes used as an explanation, namely that a productivity increase in the traded-goods sectors translates into a wage and price increase in the non-traded goods sectors, accounts for only a very small share of all this. The true explanation is the momentum of the bubble-building process, the speed of which implied a dangerous and huge overshooting of prices.

\section{Italy}

Italy was an exception of sorts. Although Italian interest rates also came down after the Madrid Summit, a boom never ignited in Italy. True, the Italian state saved more in interest payments than its value-added tax revenue, but used it for additional public expenditure. Had Italy applied the interest saved to redeem its debt, its debt-to-GDP ratio today would be just $18 \%$. Italy absorbed only modest amounts of foreign credit in the years before the crisis and never really prospered under the euro. Together with Germany, it posted the lowest growth rate of all European countries in the pre-crisis period. Nevertheless, and somewhat surprisingly, goods prices exploded, depriving Italy of its competitiveness. From 1995 to 2008, i.e. from the Madrid Summit to the Lehman collapse, Italian prices increased by $41 \%$. If we add to this the open revaluation of the Lira in 1996, Italian prices in terms of deutschmarks 
or euros increased by 55\%. Relative to the rising prices in the rest of the Eurozone, they increased by $27 \%$; relative to German prices, by $48 \%$.

\section{The necessary depreciations}

All this has to be changed by turning the price watch backwards. According to a study by Goldman Sachs Economics Research (2013), based on the price level in Q3/2010, Italy will have to cut its relative price level by $5-15 \%$ to achieve external debt sustainability, ${ }^{2}$ a rather modest depreciation thanks to the small size of its external debt position, which amounts to only $22 \%$ of GDP.

Steeper depreciations are needed for countries with higher external debt levels. According to the Goldman Sachs study, the relative prices of Spain, Greece and Portugal will have to come down by 25 - 35\% to achieve external debt sustainability. France will have to cut its relative price level by 15 - 25\%. Only Ireland would need no price adjustments to be able to service its debt. Germany, in contrast, will have to become 15 - 25\% more expensive relative to the EU average to reduce its net foreign asset position to below 25\% of GDP.

Table 1: Realignment needs in the euro area as of Q3/2010 relative to the Eurozone average*

\begin{tabular}{|l|l|l|l|}
\hline & Depreciation & Average & $\begin{array}{l}\text { Necessary price } \\
\text { cut to come to par } \\
\text { with Turkey }\end{array}$ \\
Portugal & $25-35 \%$ & $30 \%(20 \% *)$ & $30 \%$ \\
Greece & $25-35 \%$ & $30 \%(20 \% *)$ & $38 \%$ \\
Spain & $25-35 \%$ & $30 \%(27.5 \% * \star$ & \\
France & $15-25 \%$ & $20 \%$ & \\
Italy & $5-15 \%$ & $10 \%(5 \% * *)$ & \\
Ireland & Appreciation & Average & \\
Germany & $0-5 \%$ & $2.5 \%(0 \% * *)$ & \\
\hline
\end{tabular}

* Based on the GDP deflator, assuming an external adjustment of the euro exchange rates so as to keep constant the overall terms of trade of the Eurozone vis-à-vis the rest of the world.

** As of Q3/2012, taking the rescue operations and interest-reducing policies into account.

Source: Goldman Sachs Economics Research (2013); OECD Database OECD.StatExtracts, National Accounts, PPPs and exchange rates; Ifo Institute calculations.

\footnotetext{
${ }^{2}$ Goldman Sachs Economics Research (2013). It is assumed in the Goldman Sachs calculations that the average price level of the Eurozone relative to the rest of the world stays constant, such that any deviation in the average Eurozone inflation rate is automatically compensated by a change in the external value of the euro.
} 
It should be emphasized that the Goldman Sachs figures can only be interpreted roughly as giving the depreciation necessary to achieve competitiveness. What they show is the necessary realignment to achieve external debt sustainability in the sense that the net foreign asset or debt position, respectively, reduces to less than 25\% of GDP in the long run. This obviously implies that the realignment need is smaller

(i) the larger the growth rate of the country considered,

(ii) the lower the interest rate

(ii) and the larger the debt relief provided to the country in question.

Unfortunately, the new Goldman Sachs study does not inform the reader about its growth assumptions. In last year's report (Goldman Sachs Global Economics 2012), it assumed that nominal growth in Greece and Portugal was 2\%; in Ireland, Spain and Italy 3\%, and in Germany and France 4\%. Given the realignment needs, which will be discussed further below, these figures seem overly optimistic, at least for France and Spain, if they were really used for the new Goldman Sachs study as well.

The role of interest rates is important inasmuch as they came down thanks to the interventions of the ECB and the insurance protection provided to investors by the community of Eurozone states. On the one hand, these interventions drove down the market rates; on the other, they took the form of public credit, which was offered at below-market conditions. Of particular importance was the Target credit provided to the crisis countries, on the order of 948 billion euros for the six crisis countries by September 2012, which is currently being made available for the private economy at an interest rate of only $0.75 \%{ }^{3}$ The open debt relief provided to Greece in Spring 2012, together with the indirect relief through postponing and reducing interest payments, have also significantly reduced the realignment needed.

Table 1 shows in brackets the realignment needs once these public interventions are taken into account: they fall from an average of 30\% to just 20\% for Greece and Portugal, and from $10 \%$ to $5 \%$ for Italy. Trivially, they would be zero for all countries involved if all received a sufficient amount of debt relief through low interest rates and haircuts.

The realignment needs for France and Germany, by contrast, stayed at 20\%, albeit with opposite signs. The realignment need for Spain fell from 30\% to 27.5\%. Somewhat surprisingly, this figure is much higher than the estimate of $20 \%$ for Spain that Goldman Sachs had published just a year ago (see Goldman Sachs Global Economics 2012). Thus, the situation in Spain is obviously considered much more pessimistic than before.

\footnotetext{
${ }^{3}$ See Sinn and Wollmershäuser (2012a).
} 
Another approach to calculate realignment needs is based on OECD purchasing power parity (PPP) comparisons with other countries, as shown by the third column of Table 1. For Greece and, to a limited extent, Portugal, Turkey might be a suitable reference, given that that country has a flexible exchange rate determined by market forces and is on a similar development level with similar products. In 2011, Greece was 61\% more expensive than neighboring Turkey; it would thus have to depreciate by $38 \%$ to regain its competitiveness. The corresponding devaluation figure for Portugal is 30\%, since Portugal is $43 \%$ more expensive than Turkey. These figures are, as the table shows, roughly in line with the Goldman Sachs estimates that do not consider the impact of the rescue operations.

The realignment is necessary to achieve debt sustainability and regain competitiveness, and competitiveness is the pre-requisite for new growth. Growth through artificial Keynesian demand stimuli is not sustainable. At best it is an improvement in capacity utilization. Sustainable growth, by contrast, will only result if a country is truly competitive in the sense of being inexpensive enough, given the nature and quality of its products, to enjoy high demand for its products from abroad and to be an attractive business location.

\section{The devaluations achieved thus far}

The question now is how much of the necessary realignment has already been achieved by the respective countries. The answer can be found in the Eurostat data on real exchange rates. These data basically give the GDP deflator of a country relative to a weighted average of the GDP deflator of other Eurozone countries. They are reported by the curves in Figure 2, where Q3/2007, the beginning of the crisis, is set equal to 100 .

The chart shows that, unfortunately, not much has happened during the crisis. Most of the troubled countries either became even more expensive relative to their competitors than before, or stayed on the same relative price level. From Q3/2007 to Q2/2012, the relative Spanish and Portuguese prices fell by $1.2 \%$. The Greek relative price level, by contrast, increased by 3.7\%, which is roughly the effect of indirect tax increases.

Germany's relative price level declined by $2.1 \%$, while France’s increased by $0.9 \%$, both moving in the wrong direction.

Only the Irish relative price level changed to a significant degree. From Q3/2007, the first quarter after the interbank market first seized up, to Q2/2012, it declined by $14 \%$. But the Irish prices had begun to come down even earlier, after the Irish real estate bubble burst in 2006. From the peak in Q3/2006 to Q2/2012, the Irish price level fell by 15\% relative to the 
rest of the Eurozone. Together with the interest relief, the rescue funds and the low-interest policy of the ECB, this realignment has turned the Irish current account deficit from strongly negative to slightly positive.

Figure 2: Real exchange rates: development and necessary realignment

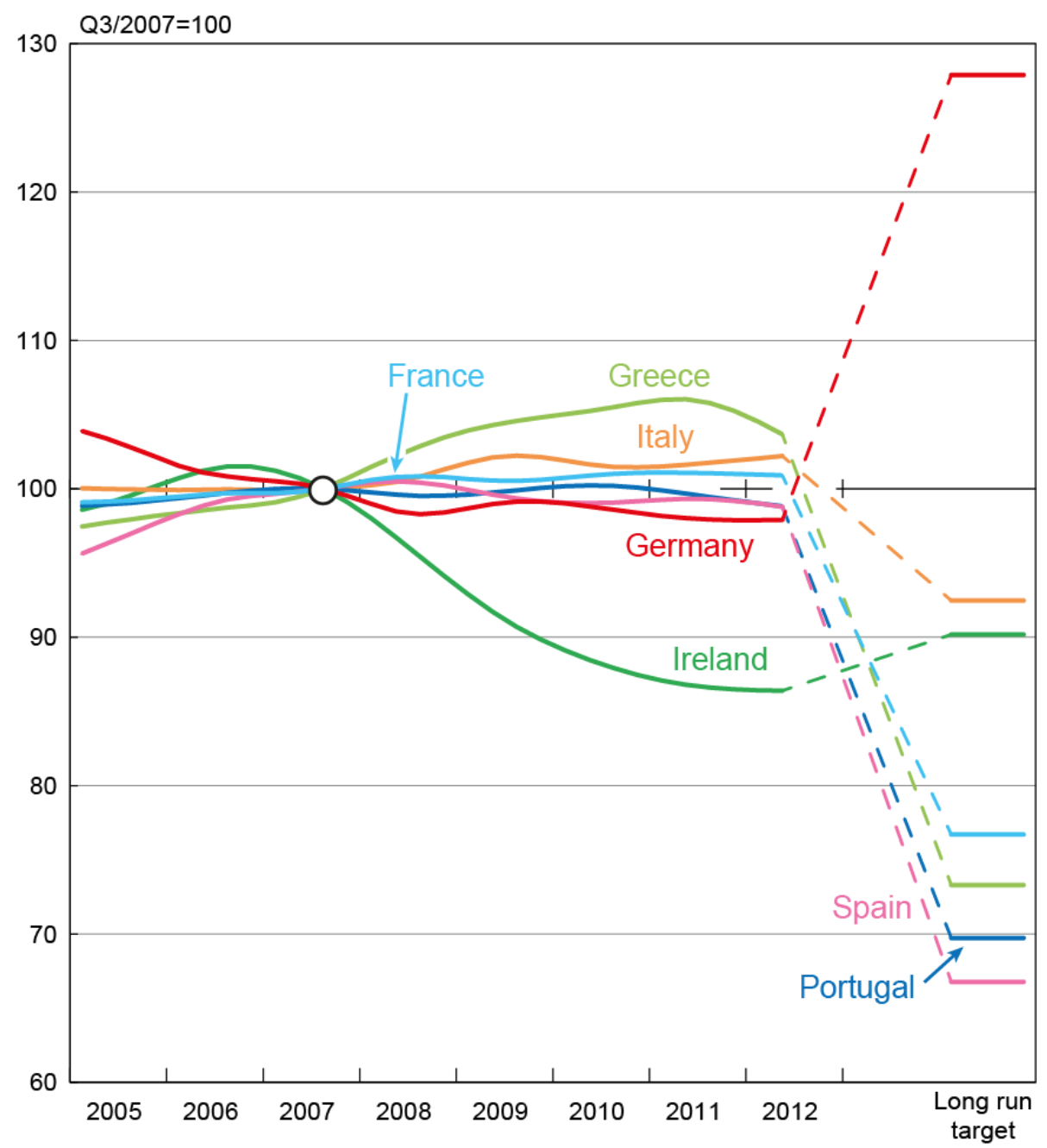

Source: European Commission, Economic and Financial Affairs, Economic databases and indicators, Price and Cost Competitiveness; Goldman Sachs Economics Research (2013); Ifo Institute calculations.

Why did Ireland succeed in cutting its relative prices, while the other crisis countries failed? The answer seems to be that Ireland's bubble burst already in 2006, while the other countries lurched into their respective crises after the Lehman debacle in autumn 2008. Whereas Ireland had to help itself by instituting wage and price cuts, the other crisis-stricken countries preferred to have their financial problems solved by collective rescue operations via 
the ECB, EFSF and ESM. Ireland later also benefited from these operations, but it remains the only country that has managed a sizeable real depreciation.

The chart also illustrates the difference between the depreciation already achieved and the average target price level according to the Goldman Sachs study. For this purpose, the Goldman Sachs figures were recalculated so that they fit the Eurostat definition of the reference price level against which the necessary revaluations and devaluations are to be seen ("rest of Eurozone" instead of "Eurozone average"). This is the reason why the realignment percentages shown in the figure exceed those in Table 1 for the bigger countries. Plainly, Greece, Spain and Portugal have a particularly long way to go to achieve debt sustainability, but practically none of the necessary adjustment has taken place yet, despite the fact that the crisis has lasted already more than five years. To a certain extent, this also applies to France and Germany, which have to devalue and revalue, respectively, by about 20\% against the average which, translated into the Eurostat definition of a real exchange rate, implies devaluations and revaluations against the respective rest of the Eurozone of 24\% (France) or 30\% (Germany).

\section{Other indicators}

Instead of looking at the GDP deflator, it may also be useful to look up the Eurostat figures for export prices. However, this does not improve the picture. With the exception of Spain, in all crisis countries export prices relative to the rest of the Eurozone declined by even less than the GDP deflator. ${ }^{4}$ The same was true for France, whereas in Germany export prices declined by even more than the GDP deflator. All this is bad news inasmuch as it dwarfs the hope that the true improvement in competitiveness is larger than suggested by the GDP deflator, since the Balassa-Samuelson effect may have hidden the true improvement in price competitiveness. For example, differential productivity increases in tradeables could have translated into wage increases and hence price increases of non-tradeables that compensated the reduction in the price of tradeables, hiding the true improvements in competitiveness. The fact that export prices fell by less than the GDP deflator rules this possibility out.

And although Spain is an exception, its export prices did not really come down all that much. While its GDP deflator declined by $1.2 \%$ relative to the rest of the Eurozone from Q3/2007 to Q2/2012, its export prices relative to the rest of the Eurozone declined by 2.0\%, just 0.8 percentage points more than the GDP deflator.

\footnotetext{
${ }^{4}$ European Commission, Economic and Financial Affairs, Price and Cost Competitiveness - Data Section, http://ec.europa.eu/economy_finance/db_indicators/competitiveness/data_section_en.htm.
} 
The only thing that has improved in some crisis countries are relative unit labor costs. From Q3/2007 to Q2/2012, they came down by 8.6\% in Greece, 6.2\% in Portugal, and 9.9\% in Spain, and increased by 1.6\% in France and 1.9\% in Italy. Some of these changes are larger than the respective reductions in the GDP deflators, but others even go in the wrong direction.

However, caution is called for. For one thing, unit labor cost reductions improve the competitiveness only if, and to the extent that, they reduce a country's goods prices. If they don't, they do not improve the country's competitiveness. They are instrumental variables at best, and by no means alternative measures of competitiveness as many seem to believe.

For another, unit labor costs tend to improve during a crisis simply because jobs and firms with high unit labor costs are wiped out first. The improvement of the average unit labor cost of the surviving jobs therefore may be little more than a statistical artifact.

When Germany suffered from its own euro crisis around 2003 and the Schröder government was forced to carry out painful social reforms, unit labor costs had improved due to the increasing mass unemployment that affected Germany. Some observers had regarded this as a sign of improvement, arguing that the painful wage reductions that the Schröder reforms implied would no longer be necessary. In fact, however, instead of an improvement in competitiveness, it was the destruction of low-skilled jobs with low labor productivity relative to wages that had improved the statistics.

A similar remark is appropriate for the improvements in the current accounts of the crisis countries. While everywhere exports and imports recovered after the Great Recession in 2009, in Q3/2012 exports were back on trend only in Ireland. In Spain and Portugal they were approaching the trend, but were still about 5\% below it, ${ }^{5}$ while in Greece they were $26 \%$ below trend in Q1/2011. The reason for the current account deficit improvements is primarily a strong decline in imports, which did not signal an improvement in competitiveness but was simply a result of the recession. Declining incomes and mass unemployment constituted an income effect that necessarily reduced imports.

What southern Europe needs is not an income effect, but a substitution effect resulting from lower relative prices, because only such a substitution effect can reduce the current accounts structurally, i.e. through improvements in competitiveness rather than an increase in unemployment. Alas, as the above analysis showed, there is no evidence of such a development yet.

\footnotetext{
${ }^{5}$ In Q3/2012, Irish exports had reached 99\% of the trend value, Spanish ones 96\% and Portuguese ones 95\%, trends calculated as linear trend in the period $2002-2007$.
} 


\section{Trapped in the euro}

Given the history of economic thought about downward price stickiness, this comes as little surprise for economists. After all, both Keynes ${ }^{6}$ and Friedman ${ }^{7}$ alike, the two great antagonists of the field, had agreed that a real devaluation through wage and price cuts is difficult if not impossible. And there is a large body of literature showing that this is the case, and why. ${ }^{8}$

In some countries there is a huge gap between the austerity programs necessary to induce sufficient price cuts to make the country competitive, and those that a society can tolerate without sliding into social unrest, if not civil war. Greek President Antonis Samaras was right when he compared Greece with the Weimar Republic. ${ }^{9}$ When Germany was forced to cut its product prices by 23\% from 1929 to 1933 by austerity programs (Brüningsche Notverordnungen or Bruning's emergency measures), there were riots in German streets and leftwing and rightwing brigades engaged in pitched street battles. The country was indeed being driven to the brink of a civil war. What came instead in 1933 was much worse.

One of the reasons for the downward stickiness of prices and wages is the resistance of unions against unilateral wage cuts. If you start by cutting wages in one sector, the union representing that sector will object, since it fears to be the only one, so that not only the absolute but also the relative income position deteriorates. Only a coordinated wage cut in all sectors can overcome this problem, but that is hard to achieve.

Another reason for the downward stickiness is that the balance sheets of companies are distorted. When all prices fall, so do the prices of the real assets a firm owns. However, the bank debt of that firm remains unchanged. This exacerbates the risk of bankruptcy.

A similar argument applies to any private debtor who has to service his debt by using part of his income, e.g. a homeowner who is servicing his debt out of current income. An internal depreciation reduces his income in nominal terms and makes it more difficult, if not impossible, to continue servicing the debt. Thus not only firm bankruptcies but also private bankruptcies have to be expected after an internal depreciation by way of wage and price cuts.

True, the Irish example does show that some real depreciation is possible. However, in the Irish case a relative price cut of only 15\% over a period of about 6 years (Q3/2006 to Q2/2012) was sufficient. It implied an absolute price reduction of just 8\%.

\footnotetext{
${ }^{6}$ Keynes (1960, p. 267).

${ }^{7}$ Friedman (1976, pp. 214).

${ }^{8}$ See for example Bewley (1999).

${ }^{9}$ See Crawford (2012). The comparison was also made by other observers. See, e.g., Sinn (2011).
} 
By contrast, Greece and Portugal need a relative depreciation of $30 \%$ or more to become competitive again and be able to service their debt without foreign help. If the Turkey price comparison is used, Greece even needs a price cut of about $40 \%$. That is quite a different order of magnitude. To achieve such cuts in relative prices one can try extreme austerity programs to depress wages, but the result would in all likelihood be mass unemployment that tears at the very fabric of society.

In Greece, the labor market situation today is already hardly sustainable, with youth unemployment exceeding $50 \%$ and an official rate of unemployment moving towards $30 \%$. This catastrophe results from the attempt to try the impossible.

\section{The exit option}

The possibly fatal problems resulting from wage and price cuts of the order required to achieve competitiveness could be avoided by exiting the euro and devaluating the new currency formally, because that is in effect a coordinated wage and price cut relative to the prices of other countries. It would redirect demand away from imports to domestic products, increase demand for the country's exports and reduce the euro value of the country's internal debt along with the euro value of internal prices, thus avoiding the balance sheet distortion for firms and indebted private households.

True, there remains a problem with external debt denominated in euros, which would increase relative to domestic income after an open devaluation. However, an internal devaluation by cutting wages and prices brings about exactly the same problem. In both cases, the problem of unbearable foreign debt levels would have to be solved by haircuts on external debt. The advantage of an open devaluation over an internal depreciation through wage and price cuts is that it avoids the internal balance sheet distortion and circumvents union resistance.

As proposed in Sinn and Sell (2012), one could offer a country, while formally staying a Eurozone member, the possibility of temporarily exiting the euro to accomplish the necessary realignment via an open devaluation. If the existing euro banknotes are given to the country, and funds are provided to recapitalize its banking sector and subsidize sensible imports while some of the external debt is forgiven, this could be organized overnight with a minimal pain and prepare the ground for a quick economic recovery.

The exit option nevertheless involves some dangers. In particular, there could be contagion effects via the capital markets, of which any trained economist could paint dramatic 
pictures. However, in my judgment the dangers of an exit are minuscule compared to the horrors resulting from a non-exit.

Apart for the risk of social strife, I see these horrors in particular in the political contagion effect resulting from a membership guarantee. If a country can be sure that it will be kept in the euro with sufficient public support from other countries, there is an incentive for this country not to attempt the painful reforms that would be necessary for an internal depreciation. That is a sure way to perpetuate the problems.

Politicians may hope to be able to push through the necessary price and wage cuts directly by resorting to political tools. However, the history of broken treaties, rules and promises in the Eurozone does not bode well. There is no reason to believe that a legislated and rule-based approach will operate better in the future than in the past. The willingness to sign declarations and commitments necessary to receive the rescue funds will always be there, but once the money is in, the commitments entered into are not taken seriously any longer.

\section{Inflating the core}

The political problems foreseeable for a strategy of internal depreciation through price cuts, as well as the market uncertainty resulting from euro exits could be avoided if the south's real depreciation could be brought about by inflating the north.

However, inflation would have to be substantial and would create new problems for the northern countries. To illustrate this, let us assume that France succeeds in accomplishing the necessary realignment in a period of ten years of stagnation with an inflation rate of zero. Since France has to devalue by $20 \%$ against the Eurozone average price level, this implies that the average annual inflation rate of the Eurozone is $2.3 \% .{ }^{10}$ Since Germany in turn needs to appreciate by $20 \%$ against the average, it would have to inflate by $4.1 \%$ per year. ${ }^{11}$ Spain in this case would have to deflate by $1.3 \%$ per year to realize a relative price cut by $30 \%$. Avoiding the Spanish price cuts would be even more demanding. If a 30\% depreciation is to be achieved with a decade of stagnation with constant Spanish prices, the average inflation rate in the Eurozone would have to be $3.6 \%$ per year, and Germany would have to inflate by $5.5 \%$ per year.

\footnotetext{
${ }^{10}$ A French devaluation of 20\% means that the Eurozone average price index grows by $25 \%$ while French prices stay constant (because 100/125=0.8).

${ }^{11}$ When the European average price level increases from 100 to 125 as shown in the previous footnote and Germany revalues by $20 \%$ relative to the average, the German price level has to increase from 100 to 150 , given that $150 / 125=1.2$. Over a period of ten years this implies an annual German inflation rate of $4.1 \%$.
} 
It is unclear though whether such a solution is politically feasible. There is a legal problem, given that the ECB's only mandate, according to the Maastricht Treaty, is to maintain price stability. ${ }^{12}$ If fluctuations in relative prices in the Eurozone are always realized without any country being driven to deflation, average inflation would necessarily violate the Treaty. From a legal perspective, a revision of the Maastricht Treaty would be necessary to choose this policy option.

Moreover, it is unclear whether the German population would accept being deprived of their savings. Given the devastating experiences Germany made with hyperinflation from 1914 to 1923, which in the end undermined the stability of its society, the resistance against an extended period of inflation in Germany could be as strong or even stronger than the resistance against deflation in southern Europe. After all, a rate of $4.1 \%$ for German inflation for 10 years, which would be necessary to allow the necessary realignment between France and Germany without France sliding into a deflation would mean that the German price level would increase by $50 \%$ and that, in terms of domestic goods, German savers would be deprived of $33 \%$ of their wealth. If the German inflation rate were even 5.5\%, which would be necessary to accommodate the Spanish realignment without price cuts, its price level would increase by $71 \%$ over a decade and German savers would be deprived of $42 \%$ of their wealth.

And although the core countries would suffer, the solution would not be comfortable for the devaluating countries either. They will unavoidably face a long-lasting stagnation with rising mass unemployment and increasing hardship for the population at large. People will turn away from the European idea and voices opting for exiting the euro will gain strength. Thus, it might be politically impossible to induce the necessary differential inflation in the Eurozone.

Apart from that it is unclear whether the ECB would be technically able to bring about inflation in the core countries. After all, its main refinancing rate is already close to zero, indicating that the Eurozone is in a classical liquidity trap, where additional money creation is unable to stimulate additional demand. Japan, whose central bank had flooded the economy with money and kept the interest rate at a level of about zero since 1997, following the bursting of its own real estate bubble in 1990, shows that the risk of secular stagnation, to use

\footnotetext{
12 "Article 105: The primary objective of the ESCB shall be to maintain price stability. Without prejudice to the objective of price stability, the ESCB shall support the general economic policies in the Community with a view to contributing to the achievement of the objectives of the Community as laid down in Article 2. The ESCB shall act in accordance with the principle of an open market economy with free competition, favouring an efficient allocation of resources, and in compliance with the principles set out in Article 3a." (Treaty on European Union, Official Journal C 191, 29 July 1992).
} 
a term that Alvin Hansen once coined, is all too real. ${ }^{13}$ Such a phase would be selfdestabilizing, since deflation would induce even more money hoarding, less aggregate demand and further deflation.

\section{Stagflation vs demand inflation}

Some politicians, such as Christine Lagarde, have argued that to bring about the required inflation in the core, the core countries should mandate higher wages through direct government actions or by encouraging unions to perform more aggressive negotiations. ${ }^{14}$ That, however, would be counterproductive as it would bring about a stagflation, i.e. a negative supply shock driving up prices through increases in the cost of production. Such a negative supply shock would not contribute to rebalancing Europe, because it would reduce the core countries' incomes and imports, which is the opposite of what the periphery countries need to improve their competitiveness and the sustainability of their debt. Theoretically, it is not even clear whether the current accounts of the core countries would really deteriorate after a dictated wage increase.

What the Eurozone needs for its internal realignment is a demand-driven boom in the core countries. Such a boom would also increase wages and prices, but it would do so because of demand rather that supply effects. Such demand-driven wage and price increases would come through real and nominal income increases in the core and increasing imports from other countries, and at the same time they would undermine the competitiveness of exports. Both effects would undoubtedly work to reduce the current account surpluses in the core and the deficits in the south.

The demand-driven boom could perhaps be artificially created in the core by extensive government borrowing, the Keynesian recipe. However, apart from doubts about the efficacy of such a policy, it would be problematic insofar as it shifts the burden of the debt to future generations. From a legal perspective, the government debt-to-GDP ratio is already large, far above the admissible 60\% limit stipulated in the Maastricht Treaty. Deficits would moreover violate the Stability and Growth Pact as well as the new rules of the Fiscal Compact enacted in 2012.

An alternative way to generate the necessary boom in the core is to simply let the market forces work. After years of extensive and excessive capital exports to the southern countries, investors from the north now have realized their mistake and look more towards

\footnotetext{
${ }^{13}$ See Hansen (1938).

${ }^{14}$ See Vinocur and Thomas (2012).
} 
investment in the home harbor. This is the reason for the investment and property boom that Germany has experienced since the summer of 2009 and that has accorded it an aboveaverage growth rate since then. After years of stagnation, mass unemployment and real depreciation which called for painful social reforms (Agenda 2010) and pushed Germany's GDP per capita from second to eighth position among the euro countries in the period from the Madrid Summit to 2008, the country has profited from a rebalancing of capital flows since the middle of 2009. Finland has profited from a similar effect.

The new boom generated in the northern countries because of the reluctance of capital exporters is exactly what Europe needs for a realignment of current account deficits. In fact, since the current account balances are by definition equal to international capital flows, a rebalancing of current accounts automatically entails a rebalancing of capital flows, implying and requiring it.

During the crisis, capital markets overreacted. This induced the ECB to shift its stock of refinancing credit from north to south, inducing the national central banks of the north to provide Target credit to the south. This led to Germany's current account surplus having been entirely absorbed by the Target credit drawn from the Bundesbank in the past few years, which is a purely public capital flow. In fact, while private capital was moving back home to Germany, public capital, primarily in the form of Target credit but also of intergovernmental credit, was flowing abroad. The public credit compensated for the dearth of private capital flows from north to south, helping to finance the current account imbalances and compensating, in addition, for outright capital flight taking the form of credit stocks being called back home from south to north. ${ }^{15}$

It is time to end this policy. If the goal is to rebalance the current accounts, re-establish competitiveness as a prerequisite of new growth, and reduce inter-country indebtedness within the Eurozone, public interventions that artificially reinstate capital flows from north to south should be reduced rather than expanded. It is a contradiction in terms if politicians argue that they want to reduce the current account imbalances in the Eurozone while, at the same time, they demand more public rescue measures that in effect replace private with public capital flows.

While public interventions into the allocative role of the capital market can be temporarily legitimated with the goal of stabilizing the economies of the south and preventing a looming crash, it is clear that, if carried out for a long period of time, they will undermine the goal of rebalancing the current accounts in the Eurozone and re-establishing

\footnotetext{
${ }^{15}$ See Sinn and Wollmershäuser (2012a and 2012b).
} 
competitiveness. This is an unavoidable policy conflict that policymakers should stop denying. They should instead acknowledge that the necessary rebalancing process of the Eurosystem will require a decade of austerity, stagnation and real devaluations in the deficit countries, coupled with an extended period of inflation in the surplus countries. It can only be hoped that the European idea will survive this strain.

\section{References}

Bewley, T.F. (1999), Why Wages Don't Fall During a Recession, Harvard University Press, Cambridge, Mass.

Crawford, A. (2012), Samaras Says Greece Like Post-World War I Weimar Republic, Bloomberg, 5 October, http://www.bloomberg.com/news/2012-10-05/samaras-saysgreece-like-post-world-war-i-weimar-republic.html.

Friedman, M. (1976), Price Theory, Aldine Publishing Company, Chicago (1st edition 1962).

Goldman Sachs Economics Research (2013), European Economics Analyst, 17 January, No. 03.

Goldman Sachs Global Economics (2012), European Economics Analyst, 15 March, No. 01.

Hansen, A. (1938), Full Recovery or Stagnation, Norton, New York.

Keynes, J.M. (1960), The General Theory of Employment, Interest and Money, Macmillan and Company Limited, London (1st edition 1936).

Sinn, H.-W. (2012), Die Target-Falle, Hanser-Verlag, München.

Sinn, H.-W. (2011), Die griechische Tragödie, Wirtschaftswoche, 11 July, No. 28, p. 37. English: Greek Tragedy, Ifo Viewpoint 125, 27 July, http://www.cesifogroup.de/de/sinn-wiwo-20110711.html.

Sinn, H.-W. (2010), Rescuing Europe, CESifo Forum Special Issue, August, pp. 1-22, http://www.cesifo-group.de/DocDL/Forum-Sonderheft-Aug-2010.pdf.

Sinn, H.-W. and R. Koll (2000), The Euro, Interest Rates and European Economic Growth, CESifo Forum 1, No. 3, pp. 30-31, http://www.cesifo-group.de/DocDL/Forum300sl1.pdf.

Sinn, H.-W. and F. Sell (2012), Our Opt-in Opt-out Solution to the Euro Crisis, Financial Times 1 August 2012, p. 9, http://www.cesifo-group.de/sinn-ftimes-20130801.html. 
Sinn, H.-W. and T. Wollmershäuser (2012a), Target Loans, Current Account Balances and Capital Flows: The ECB's Rescue Facility, International Tax and Public Finance 19(4), pp. 468-508, http://www.cesifo-group.de/DocDL/sinn-itax-2012-target.pdf.

Sinn, H.-W. and T. Wollmershäuser (2012b), Target Balances and the German Financial Account in Light of the European Balance-of-Payments Crisis, CESifo Working Paper No. 4051, December, http://www.cesifo-group.de/DocDL/cesifo1_wp4051.pdf.

Vinocur, N. and L. Thomas (2012), IMF'S Lagarde Urges Flexibility on Euro Zone Deficits, Reuters, 16 October, http://uk.reuters.com/article/2012/10/16/uk-imf-lagardeidUKBRE89F1KA20121016. 